\title{
IMMUNOCHEMICAL STUDIES OF LACTATE DEHYDROGENASE AND GLUCOSE-6-PHOSPHATE DEHYDROGENASE IN PREIMPLANTATION MOUSE EMBRYOS
}

\author{
H. SPIELMANN,* R. P. ERICKSON AND C. J. EPSTEIN \\ Department of Pediatrics, University of California, \\ San Francisco, California 94143, U.S.A.
}

(Received 16th November 1973)

\begin{abstract}
Summary. Lactate dehydrogenase and glucose-6-phosphate dehydrogenase in Day-1 and Day-4 preimplantation mouse embryos was assayed by immunotitration. For both enzymes, immunoreactive protein was found to decrease in parallel with enzyme activity, indicating that loss of activity is probably the result of enzyme degradation. The identification of embryonic lactate dehydrogenase as isoenzyme LDH-1 and of glucose-6-phosphate dehydrogenase as the form found in red cells is corroborated by the immunological data.
\end{abstract}

\section{INTRODUCTION}

High activities of lactate dehydrogenase (LDH) (E.C.1.1.1.27) and glucose6-phosphate dehydrogenase (G-6-PD) (E.C.1.1.1.49) have been detected in unfertilized ova and early preimplantation mouse embryos: 0.78 and $0.029 \mathrm{mU} /$ embryo, respectively (Brinster, 1965, 1966, 1968; Epstein, Wegienka \& Smith, 1969). These high activities remain constant until the eight- to sixteencell (Day 2) stage of development and then decline exponentially. By Day 4, the activities are about $12 \%$ of those present in the early stages (Epstein et al., 1969). Of the many mouse embryonic enzymes examined, only one other, guanidine deaminase, behaves in a similar manner (Epstein \& Daentl, 1972). All others either increase or remain constant during the preimplantation period (Epstein \& Daentl, 1972). The decline in LDH and G-6-PD activity is not, therefore, a general phenomenon of preimplantation mouse embryonic enzymes but represents a specific event involving these enzymes. No evidence for the presence of soluble inhibitors or activators has been found (Epstein et al., 1969), and the present immunological studies were therefore undertaken to determine whether the decreases in enzyme activity are associated with concomitant decreases in enzyme protein.

\footnotetext{
* Present address : Pharmakologisches Institut, Abt. Embryonal-Pharmakologie der Freien Universität, 1 Berlin 33, Thielallee 69/73, West Berlin, Germany.
} 


\section{MATER IALS AND METHODS}

Preimplantation mouse embryos were obtained from 16- to 18-g Swiss-Webster females following superovulation and the embryonic enzymes were prepared and assayed as previously described (Epstein et al., 1969). All reagents were purchased from the Sigma Chemical Co., St Louis, Mo., U.S.A.

\section{Lactate dehydrogenase studies}

The LDH was purified from mouse testes by affinity chromatography and the LDH isoenzymes 1 to 5 were separated by polyacrylamide gel electrophoresis (Spielmann, Erickson \& Epstein, 1973). In order to overcome the low antigenic activity of $\mathrm{LDH}-1$, polyacrylamide was used as adjuvant as described elsewhere (Spielmann et al., 1974). The disc containing LDH-1 was cut from the gel and, after homogenization, it was injected into male New Zealand white rabbits with Freund's adjuvant. A specific inhibitory antibody against LDH-1 of the mouse could be produced by this procedure. The LDH activity of the rabbit serum was removed from the antibody by $\left(\mathrm{NH}_{4}\right)_{2} \mathrm{SO}_{4}$ precipitation for the immunotitration (Spielmann et al., 1974).

The tissue $\mathrm{LDH}$ preparations were the $20,000 \mathrm{~g}$ supernatants of $1: 10$ homogenates of mouse heart and muscle in $0.02 \mathrm{M}$-tris- $\mathrm{HCl}, \mathrm{pH} 7 \cdot 4$. These represent predominantly LDH-1 and LDH-5, respectively. A preparation of LDH-X was made by removing LDH enzymes 1 to 5 by affinity chromatography from a similarly prepared homogenate of mouse testes (Spielmann et al., 1973).

For the immunotitration of $\mathrm{LDH}$, all enzyme preparations were brought to an activity of $67 \mathrm{mU} / \mathrm{ml}$. To $25 \mu \mathrm{l}$ of such an enzyme preparation, $25 \mu \mathrm{l}$ of 50 mM-phosphate buffer, $\mathrm{pH} 7 \cdot 4$, were added and served as $100 \%$ control. Increasing volumes of buffer were replaced by anti-LDH-1 antiserum in the inhibition studies. These solutions were mixed, incubated for $30 \mathrm{~min}$ at $25^{\circ}$, and cooled to $0^{\circ} \mathrm{C}$. Thereafter, $10 \mu \mathrm{l}$ of the mixture were assayed for residual enzyme activity (Epstein et al., 1969). The results are expressed as a percentage of the enzyme activity remaining from the initial which is given by the control. The amount of antiserum added in $\mu \mathrm{l} / \mathrm{mU} \mathrm{LDH}$ is indicated in Text-figs 1 to 4 as $\mathrm{ml} /$ unit (unit $=$ i.u. $\mathrm{LDH}$ ).

\section{Glucose-6-phosphate dehydrogenase studies}

Freeze-thaw lysates of red cells and embryos were made in the assay buffer, and the G-6-PD activities were adjusted to $167 \mathrm{mU} / \mathrm{ml}$ for comparison of mouse red blood cells with human red blood cells and to $42 \mathrm{mU} / \mathrm{ml}$ for comparison of mouse embryo with mouse red blood cells. The immunological inhibition studies were performed as described above for $\mathrm{LDH}$.

\section{RESULTS}

\section{Lactate dehydrogenase}

The rabbit anti-mouse LDH- 1 did not inhibit either mouse muscle ('LDH-5') or testicular (LDH-X) LDH (Text-fig. 1). It did, however, produce an $80 \%$ 


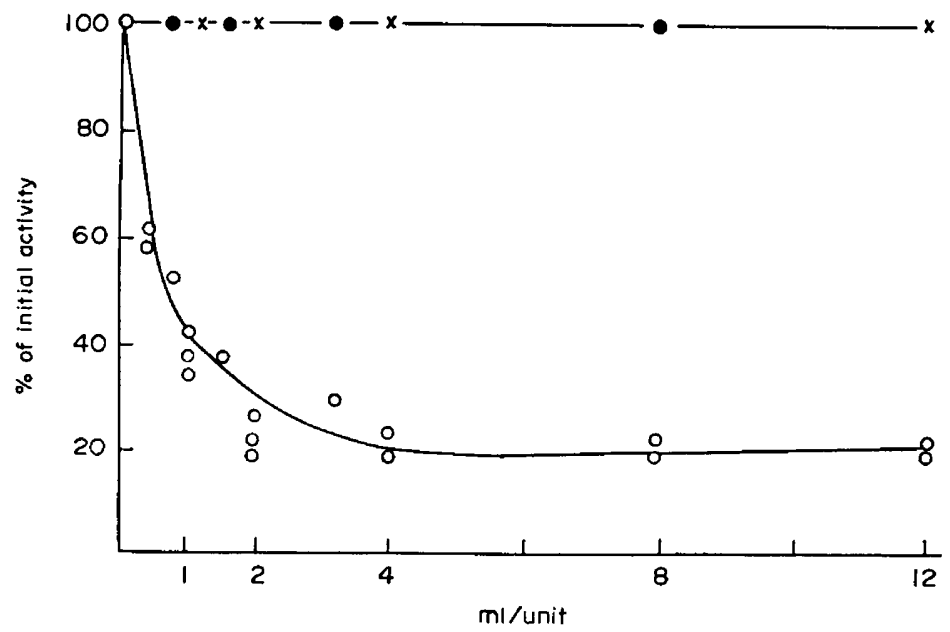

Text-FIG. 1. Inhibition of lactate dehydrogenase (LDH) of different mouse tissues by increasing amounts of anti-mouse LDH-1 antiserum. O, LDH-heart; $0, \mathrm{LDH}$-muscle; $x, \mathrm{LDH}$-testes, an extract containing only LDH-X.

inhibition of mouse heart ('LDH-1') $\mathrm{LDH}$ activity. The remaining $20 \%$ activity could not be inhibited with high concentrations of antibody. When extracts of Day-1 and Day-4 embryos were titrated with anti-LDH-1, inhibition curves identical to one another and to that previously obtained with the mouse heart extract were obtained (Text-fig. 2). A similar behaviour was obtained with extracts prepared from oocytes.

\section{Glucose-6-phosphate dehydrogenase}

The anti-human red cell G-6-PD partly cross-reacted with mouse red cell

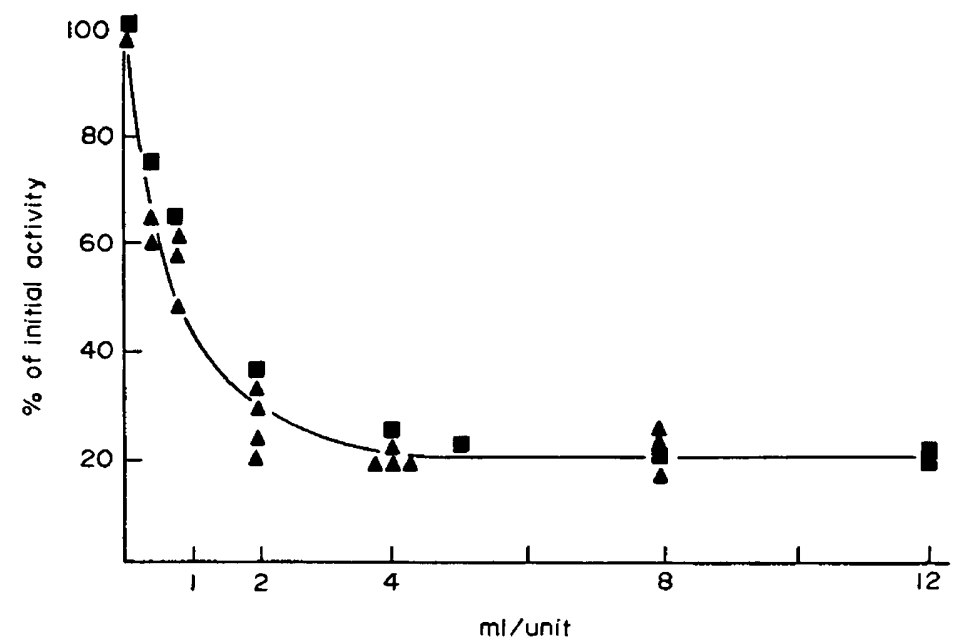

TExT-FIG. 2. Inhibition of embryonic lactate dehydrogenase (LDH) ( $\Delta$, Day-1 embryo; a, Day-4 embryo) by increasing amounts of an anti-mouse LDH-1 antiserum. The curve indicates the reaction of mouse heart LDH with the same antiserum (from Text-fig. 1). 


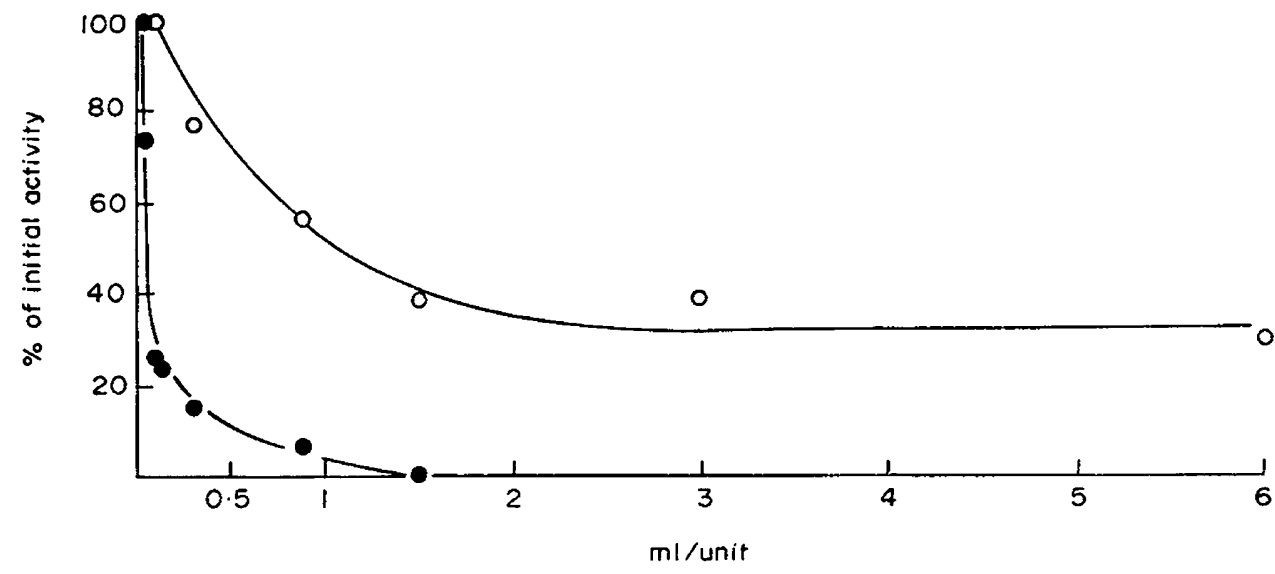

TEXT-FIG. 3. Inhibition of human ( $)$ and mouse ( 0 ) erythrocytic glucose-6-phosphate dehydrogenase (G-6-PD) by increasing amounts of anti-human G-6-PD antiserum.

G-6-PD (Text-fig. 3). While the human red cell G-6-PD was completely inhibited, however, the same ratios of antibody to mouse red cell enzyme activity resulted in a maximal inhibition of only $60 \%$ (only $40 \%$ residual activity). It thus appears that human and mouse red cell G-6-PD have similar but not identical antigenic determinants.

Because of the relatively high residual activity and the lower enzyme activities used in the immunotitrations, the scatter of the data from the embryos was somewhat greater than that observed with LDH. Nevertheless, when preparations from Day-1 and Day-4 embryos were compared with red cell G-6-PD, they were again found not to differ significantly from one another (Text-fig. 4).

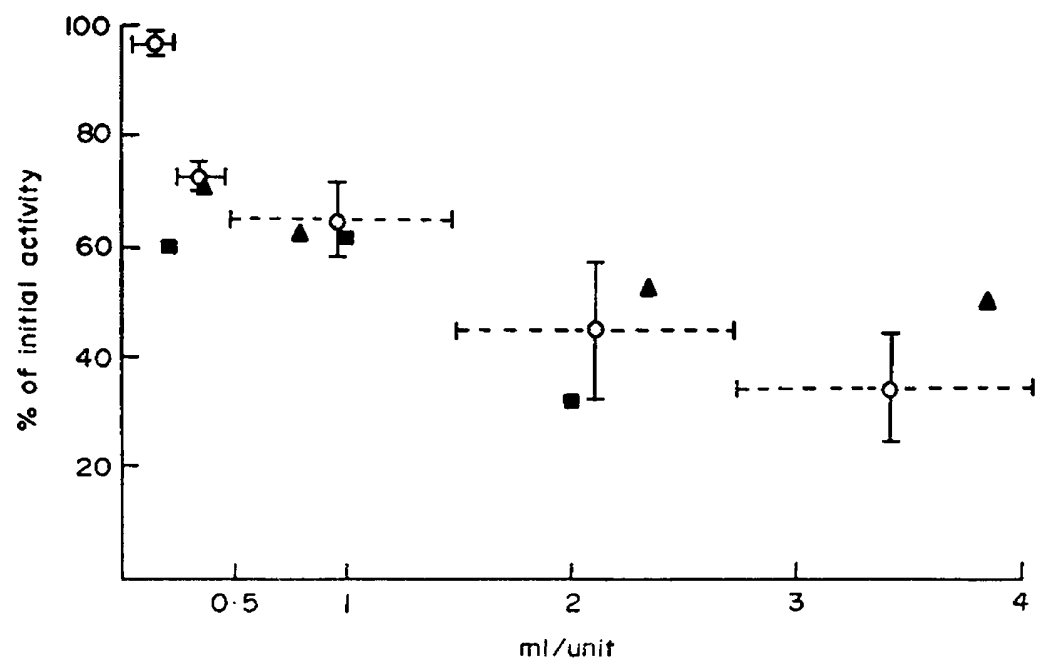

TEXT-FIG. 4. Inhibition of (O) mouse erythrocytic glucose-6-phosphate dehydrogenase (G-6-PD) given with standard errors (for intervals along the ordinate indicated by the horizontal dashed lines) and embryonic G-6-PD ( $\Lambda$, Day-1 embryo; $\mathbf{m}$, Day-4 embryo) by increasing amounts of anti-human G-6-PD antiserum. 


\section{DISCUSSION}

With both LDH and G-6-PD, the immunotitrations of extracts from Day-1 and Day-4 embryos indicate that equal activities of enzyme from these two stages correspond to equal amounts of immunoreactive enzyme protein. Therefore, the declines in LDH and G-6-PD activity between Days 1 and 4 of embryonic development represent concomitant losses of immunologically detectable enzyme protein.

Although prepared against LDH-1 from mouse, the rabbit anti-LDH-1 serum did not completely inhibit mouse heart and embryonic LDH activity, although they both behave electrophoretically as LDH-1. This lack of complete inhibition, even with an excess of antibody, is predicted by hypotheses for antibody-induced enzyme inhibition which invoke alterations in enzyme conformation with a qualitative change in function rather than an 'all-or nothing' effect on enzyme activity. Such mechanisms seem to apply to trypsin and pancreatic ribonuclease (Erickson, 1974). Nevertheless, the immunotitration data clearly indicate that embryonic LDH does behave immunologically as LDH-1. Similar considerations also apply to the G-6-PD immunotitration system, and the immunological similarity of mouse embryonic and red cell G-6-PD can be inferred.

The mechanism(s) by which exponential declines of G-6-PD and LDH activity and, as is shown here, of G-6-PD and LDH protein, are produced is unknown. The decrease in enzyme protein is most reasonably explained by a degradation process, not necessarily the same for both enzymes. Although the presence of soluble inhibitors or activators is ruled out by the earlier work (Epstein et al., 1969) as well as by the present data, it is conceivable, though unlikely, that there are macromolecular inhibitors which both inhibit enzyme activity and interfere with immunoreactivity to the same extent. It is concluded, therefore, that degradation of G-6-PD and LDH enzyme protein begins after the eight- to sixteen-cell stage and proceeds in an exponential manner. Given this conclusion, it is still necessary to explain the timing and specificity of the process. One possibility, for which there is no evidence, is that a specific protease (or proteases) appears which reacts only with those enzymes which decline in activity. Another is that there is a general increase in protein degradation starting on Day 2. If this were the case, the synthesis of the other enzymes which either remain constant or increase in activity would have to increase to an extent which would compensate for the increased proteolysis. While protein synthesis does increase significantly at this time (Epstein \& Smith, 1973), the protein mass of the embryo does also (Brinster, 1967b), and it would seem unlikely that there would be increased protein degradation concomitant with net protein synthesis. Furthermore, this type of mechanism would necessitate very precisely matched increases in the synthesis of those enzymes such as malate dehydrogenase and aldolase which remain relatively constant in activity (Epstein et al., 1969).

Two other possibilities require consideration. One is that synthesis and degradation of LDH and G-6-PD are equal and balanced before Day 2, and that synthesis then ceases. Verification of this hypothesis would require 
that the occurrence of these two processes be actually demonstrated, and this has not been accomplished. The other possibility is that neither synthesis nor degradation of these enzymes is occurring during the early preimplantation period, and that a metabolic change in the cell leads to the degradation of the enzymes. This could involve a decline in the concentrations of metabolites which might stabilize the enzymes against normal degradation or, conversely, an increase in the concentration of destabilizing metabolites. Again, there is no evidence for or against this possibility. While earlier studies on the effects of cycloheximide (Epstein et al., 1969) and actinomycin D (Auerbach, 1969) have been interpreted as indicating that degradation was not occurring, these agents lead to a general interference with embryonic function and conclusions based on their use are open to question.

The activities of LDH and G-6-PD in preimplantation mouse embryos, as well as in other species, were first measured as part of metabolic studies during this stage of development (Brinster, 1965, 1966, 1967a). Using electrophoretic methods, Auerbach \& Brinster (1967) and Rapola \& Koskimies (1967) then demonstrated that only LDH-1 was present in the preimplantation mouse embryo. Although Gibson \& Masters (1970) asserted that the preimplantation embryo contained only LDH- 5 and that this enzyme was adsorbed from the oviducal fluid, the presence of predominantly LDH-1 in those strains of embryos being investigated in the previous studies was reaffirmed and an external origin was ruled out (Epstein, Kwok \& Smith, 1971; Brinster, 1971). The identical reaction of mouse heart LDH and mouse embryo LDH from Days 1 and 4 in the present immunotitration study further confirms that the embryonic LDH is indeed LDH-1. Similar data have been obtained by Sorenson (1972) using anti-LDH-1 and anti-LDH-5. Only the former was inhibitory, and disruption of the embryo to expose the cytoplasm was necessary.

In a previous investigation, it was demonstrated by kinetic measurements, substrate specificity studies and gel electrophoresis that the G-6-PD in mouse embryos is indistinguishable from the major G-6-PD component in mouse red cells (Epstein, Smith \& Kwok, 1970). These results are substantiated by the present immunological study.

\section{AGKNOWLEDGMENTS}

The work was supported by grants from the Population Council, New York and the National Institutes of Health, Bethesda, Md (HD-03132). One of us (H.S.) was supported by a grant from the Deutsche Forschungsgemeinschaft given to the Sonderforschungsbereich 29 and by the Freie Universität, Berlin, Germany, and R.P.E. is the recipient of a Research Career Development Award from the National Institute of Child Health and Human Development.

The rabbit anti-human red cell G-6-PD was the kind gift of Dr Akira Yoshida (City of Hope Medical Center, Duarte, California).

\section{REFERENCES}

Auerbach, S. (1969) Lactate dehydrogenase isozymes in the early mouse embryo. Ph.D. thesis, University of Pennsylvania. 
Auerbach, S. \& Brinster, R. L. (1967) Lactate dehydrogenase isozymes in the early mouse embryo. Expl Cell Res. 46, 89.

Brinster, R. L. (1965) Lactic dehydrogenase activity in the preimplantation mouse embryo. Biochim. biophys. Acta, 110, 439 .

Brinster, R. L. (1966) Glucose-6-phosphate dehydrogenase in the preimplantation mouse embryo. Biochem. 7. 101, 161.

Brinster, R. L. (1967a) Lactate dehydrogenase activity in the preimplantation rabbit embryo. Biochim. biophys. Acta, 148, 298.

Brinster, R. L. (1967b) Protein content of the mouse embryo during the first five days of development. 7. Reprod. Fert. 13, 413.

Brinster, R. L. (1968) Lactate dehydrogenase activity in the oocytes of mammals. F. Reprod. Fert. 17, 139.

BRINSTER, R. L. (1971) The lactate dehydrogenase in the preimplantation mouse embryos of Quackenbush and Swiss mice. FEBS Letters, 17, 41.

Epstein, C. J. \& DAente, D. L. (1972) Molecular events in preimplantation mammalian development. In Cell Differentiation, pp. 69-72. Eds. R. Harris, P. Allin and D. Viza. Munksgaard, Copenhagen.

Epstein, G. J., Kwok, L. \& SмrтH, S. (1971) The source of lactate dehydrogenase in preimplantation mouse embryos. FEBS Letters, 13, 45.

Epstein, C. J., Smrth, G. W. \& Kwok, L. W. (1970) The characterization of glucose-6-phosphate dehydrogenase in mouse ova. 7. Reprod. Fert. 21, 179.

Epstein, C. J. \& Sмiтh, S. A. (1973) Amino acid uptake and protein synthesis in preimplantation mouse embryos. Devl Biol. 33, 171.

Epstein, C. J., Wegienka, E. A. \& Smith, C. W. (1969) Biochemical development of preimplantation mouse embryos: in vivo activities of fructose 1,6-diphosphate aldolase, glucose-6-phosphate dehydrogenase, malate dehydrogenase, and lactate dehydrogenase. Biochem. Genet. 3, 271.

ERICKSON, R. P. (1974) Inactivation of trypsin by antibodies of high affinity. Immunochemistry, $11,41$.

Gibson, G. \& Masters, G. J. (1970) On the lactate dehydrogenase of preimplantation mouse ova. FEBS Letters, 7, 277.

Rapola, J. \& Koskimies, O. (1967) Embryonic enzyme patterns : characterization of the single lactate dehydrogenase isozyme in preimplanted mouse ova. Science, $\mathcal{N} . \Upsilon .157,1311$.

Sorensen, R. A. (1972) Problems in oocyte maturation and early development in the mouse. Ph.D. thesis, Yale University.

Spielmann, H., ERickson, R. P. \& Epstein, G. J. (1973) The separation of lactate dehydrogenase X from other lactate dehydrogenase isozymes of mouse testes by affinity chromatography. FEBS Letters, 35, 19.

Spielmann, H., Erickson, R. P. \& Epstein, C. J. (1974) The production of antibodies against mammalian LDH-1. Analyt. Biochem. 59, 462. 